\title{
Comparison of antifungal activity of selected essential oils against Fusarium graminearum in vitro
}

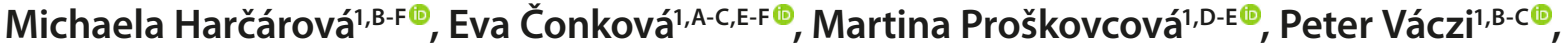 \\ Dana Marcinčáková1,E-F® , Lukáš Bujňák ${ }^{1, E \oplus ~}$ \\ ${ }^{1}$ University of Veterinary Medicine and Pharmacy, Košice, Slovak Republic \\ A - Research concept and design, B - Collection and/or assembly of data, C - Data analysis and interpretation, \\ $D$ - Writing the article, E - Critical revision of the article, F - Final approval of article
}

\begin{abstract}
Harčárová M, Čonková E, Proškovcová M, Váczi P, Marcinčáková D, Bujňák L. Comparison of antifungal activity of selected essential oils against Fusarium graminearum in vitro. Ann Agric Environ Med. 2021; 28(3): 414-418. doi: 10.26444/aaem/137653
\end{abstract}

\begin{abstract}
Introduction. Fusaria are microscopic filamentous fungi which are spread in soil, in various organic substrates, and include more than 80 phytopathogenic species which are predominantly hosted by cereals, fruits and vegetables. Many of these species, under certain conditions, are capable of synthesizing secondary metabolites, mycotoxins. At present, various substances are used for their elimination and one of the solutions appears to be essential oils. In the presented study, the antifungal activity of essential oils was researched in vitro.

Materials and method. In this study, two standard fungal isolates Fusarium graminearum CCM F-683 and Fusarium graminearum CCM 8244 (Brno, Czech Republic) were used. The antifungal effect of 6 tested essential oils (Syzygium aromaticum, Origanum vulgare, Thymus vulgaris, Hyssopus officinalis, Ocimum basilicum, Myristica fragrans) was determined using the broth microdilution method, which allows reading of the MIC (minimum inhibitory concentration). According to the results obtained, the growth inhibition of Fusarium graminearum was determined by assay for the inhibition of radial growth of the mycelium.

Results. The inhibitory effects of thymus, oregano, basil, myristica, hyssop and syzygium essential oil (EO) on mycelial growth of Fusarium graminearum CCM F- 683 and CCM 8244 were investigated. The best antifungal activity against the both strains of Fusarium graminearum (37.4\%; 40.7\%) was demonstrated by Origanum vulgare EO at the concentration $100 \mu \mathrm{g} / \mathrm{mL}$. Among the four tested oils, three (Syzygium aromaticum, Thymus vulgaris, Origanum vulgare) achieved the best inhibitory effect (100\%) at concentrations $500 \mu \mathrm{g} / \mathrm{mL}$ and $1000 \mu \mathrm{g} / \mathrm{mL}$.

Conclusions. In the protection of plants against pathogenic fungi, essential oils appear to be a suitable substitute for synthetic chemicals.
\end{abstract}

Key words

comparison, essential oils, antifungal activity, Fusarium graminearum, microscopic filamentous fungi

\section{INTRODUCTION}

The production of healthy agricultural crops is the basis for the production of quality food and feed. The presence of microscopic filamentous fungi and their secondary metabolites in agricultural commodities is the most common worldwide problem. The micromycetes which can infect grain before harvesting, are Fusarium spp., Cladosporium spp. and Alternaria spp. In Europe, the main contaminant of the cereals is Fusarium graminearum [1], a species that may occur among many types of cereals and cultured grasses, and parasitizes their roots, stems, leaves and reproductive tissues. The main cereal host species are wheat and corn, but it is also found on rye, oats and rice [2]. The phytopathogen Fusarium graminearum causes a disease of wheat and barley called Fusarium head blight or scab [3]. The occurrence of mycotoxins is a global problem and it is estimated that $25 \%$ of total crops production is contaminated [4].

Fusarium graminearum was described in 1838 and is classified in Ascomycota phylum (class: Sordariomycetes, order:

Address for correspondence: Michaela Harčárová, University of Veterinary Medicine and Pharmacy in Košice, Slovak Republic

E-mail: michaela.harcarova@uvlf.sk

Received: 28.09.2020; accepted: 18.05.2021; first published: 10.06.2021
Hypocreales, family: Nectriaceae). The sexual stage (teleomorph) of Fusarium graminearum is called Gibberella zeae [5]. Fusarium graminearum is the major producer of secondary metabolites as trichothecenes (deoxynivalenol, nivalenol) and zearalenone [6]. The most detected mycotoxins in Europe are deoxynivalenol and zearalenone [7], which can cause chronic and acute mycotoxicosis in humans and animals [8]. Zearalenone has an estrogenic effect and may stimulate the growth of human breast cancer cells. The group of trichothecenes is classified as gastrointestinal toxins, dermatotoxins, immunotoxins, hematotoxins, and gene toxins. Although deoxynivalenol is less toxic, it can cause the human gastroenteritis [9]. The most important mycotoxicosis in animals are Zearalenone-Syndrome of swine [10], equine leukoencephalomalacia (ELEM) [11], porcine pulmonary edema (PPE), among others [12].

The incidence of microscopic filamentous fungi and mycotoxins cannot be completely inhibited, therefore the possibilities of their elimination are being investigated. At present, adsorbents, antioxidants and biologically active substances are used as feed additives. In addition to good agricultural practice and the use of chemical protection of crops, essential oils are also proving to have antifungals effects $[13,14,15]$. 
Essential oils (EOs) are important components of many plants, where they are found in the secretory trichomes or mucosal canals. EOs not only protect plants against insects, but also against bacteria and fungi attack [16]. Plant essential oils are composed from mixture of monoterpenes, diterpenes, sesquiterpenes and their oxidatives derivatives such as alcohols, aldehydes, ketones, ethers, esters, phenols and oxides $[17,18]$. Essential oils are often used in cosmetics and pharmaceutical industry [19]. The alternative use of EOs as biological pesticides is an important element of modern organic farming [16].

\section{MATERIALS AND METHOD}

Microorganisms. Two standard fungal isolates Fusarium graminearum CCM F-683 and Fusarium graminearum CCM 8244 (Czech Collection of Microorganisms, Masaryk University, Faculty of Science, Brno, Czech Republic) were used. The isolates were cultivated on to Potato Dextrose Agar - PDA (HiMedia, Laboratories Pvt., Ltd., Mumbai, India) and incubated for 10 days at laboratory temperature $25^{\circ} \mathrm{C} \pm 1^{\circ} \mathrm{C}$.

Fungal inoculum preparation. The suspensions containing fungal conidia were prepared by harvesting from 10-day-old Fusarium graminearum samples (CCM F-683 and CCM 8244 ) cultured on PDA. Twenty $\mathrm{ml}$ of $0.1 \%$ Tween 80 was added to the surface of fungal cultures to release and pick up the conidia from the mycelium. The density of fungal conidia inoculum $10^{6} \mathrm{CFU} / \mathrm{ml}$ (McFarland 2) was adjusted by adding saline solution and using a densitometer (Pliva-LaChema a.s., Brno, Czech Republic).

Essential oils. To test the growth inhibition of Fusarium graminearum, 6 certified essential oils were used, produced and analysed by the Calendula Company, Nová Lubovňa, Slovakia. Essential oils Origani aetheroleum (carvacrol 85 $\pm 3 \%$; Origanum vulgare), Basiliciaetheroleum (metylchavicol $75 \pm 2 \%$; Ocimum basilicum), Hyssopi aetheroleum (a-pinene $11 \pm 1 \%$, pinocampfen $50 \pm 2 \%$, izopinocampfen $28 \pm 1 \%$; Hyssopus

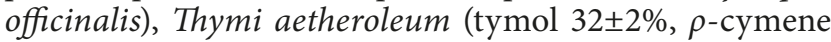
$40 \pm 3 \%$; Thymus vulgaris), Caryophylli aetheroleum (eugenol 85 $\pm 3 \%$; Syzygium aromaticum) and Myristicae fragrantis aetheroleum (myristicine $5.0 \pm 0.2 \%$, $\alpha$-pinene $18 \pm 1 \%, \beta$-pinene $13 \pm 1 \%$, satinene $14 \pm 1 \%$, Myristica fragrans) were obtained by hydrodistillation, and their chemical composition identified by gas chromatography. The $400 \mathrm{mg} / \mathrm{mL}$ stock solutions of EOs were prepared by dilution with paraffin oil. The lower concentrations of each essential oil $(0.4-200 \mathrm{mg} / \mathrm{mL})$ were diluted directly on the microdilution plate.

Determination of antifungal effect of EOs. The antifungal effect of tested essential oils was determined using the broth microdilution method [20] which allows reading of the MIC (minimum inhibitory concentration). Sterile 96-well microtiter plates (form U) were used for testing and Potato Dextrose Broth - PDB as the cultivation medium. First, $100 \mu \mathrm{l}$ of PDB was applied into wells, Nos. $2-12$, and $200 \mu \mathrm{l}$ of $400 \mathrm{mg} / \mathrm{mL}$ EO to well No. 1 . Then $100 \mu \mathrm{l}$ of EO from the first well was transferred to well No. 2 . This procedure was repeated until well No. 10 and the remaining $100 \mu \mathrm{l}$ was discarded. To wells 1-10 were added $100 \mu \mathrm{l}$ fungal inoculum, except for line $\mathrm{H}$, which served as negative control and contained $100 \mu \mathrm{PDB}$ and $100 \mu \mathrm{l} \mathrm{EO}$. Well No. 11 (negative control) was the sterility control and contained $200 \mu \mathrm{lPDB}$. As positive control, well No. 12 with $100 \mu \mathrm{PDB}$ and $100 \mu$ fungal inoculum was used. The microtiter plates were incubated at $25^{\circ} \mathrm{C} \pm 1{ }^{\circ} \mathrm{C}$ for $72 \mathrm{~h}$ in darkness [20]. After $48 \mathrm{~h}$ incubation, $15 \mu \mathrm{l}$ of $0.1 \%$ resazurine solution was added into wells $\mathrm{A}-\mathrm{E}$ and $\mathrm{H}$ for better visualisation of the inhibition effect [21]. Absorbance was measured using the ELISA reader (Dynex Technologies, Inc., Virginia, USA) at $630 \mathrm{~nm}$. The percentage of EO inhibition effect (IE) was calculated according to the formula:

$$
I E(\%)=\frac{(\mathrm{PC}-\mathrm{NC})-(\mathrm{S}-\mathrm{NC})}{\mathrm{PC}-\mathrm{NC}} \times 100
$$

$I E$ - inhibitory effect

$\mathrm{PC}$ - absorbance of the positive control

$\mathrm{NC}$ - absorbance of the negative control

$\mathrm{S}$ - absorbance of the sample

The MIC was considered the lowest concentration of EO completely inhibited the growth of Fusarium graminearum mycelium. The antifungal activity of EO was determined in five repetitions.

Assay for inhibition of radial growth of mycelium Fusarium graminearum. To evaluate the inhibitory effect of essential oils on the radial growth of Fusarium graminearum mycelium, the method described by Badawy and Abdelgaleilwas used. The antifungal activity of selected EOs were estimated by measuring the diameter of radial mycelium growth of Fusarium graminearum CCM F-683 and CCM 8244. Finally, the inhibition of radial mycelium growth by the agents we evaluated, compared to the control [22].

Fungal inoculum preparation. For testing, 10-dayold cultures of Fusarium graminearum CCM F-683 and Fusarium graminearum CCM 8244 cultured on PDA medium at laboratory temperature $\left(25^{\circ} \mathrm{C} \pm 1^{\circ} \mathrm{C}\right)$ in the dark, were used.

Preparation of essential oils. The same certified EOs were tested as in the microdilution broth method. The plant essential oils (Origanum vulgare, Hyssopus officinalis, Thymus vulgaris and Syzygium aromaticum) were chosen on the basis of the MIC results (experiment described above). EOs were diluted in a sterile dimethyl sulfoxide (DMSO) (Sigma Aldrich, Schnelldorf, Germany) to $100 \mathrm{mg} / \mathrm{mL}$ and $500 \mathrm{mg} / \mathrm{mL}$ concentrations.

Test procedure. Essential oils dissolved in DMSO $(100 \mathrm{mg} / \mathrm{mL}$ or $500 \mathrm{mg} / \mathrm{mL}$ ) were added to the PDA medium before being poured into Petri dishes $(6 \mathrm{~cm})$ at $40-45^{\circ} \mathrm{C}$ to obtain final concentrations of $1,000 \mu \mathrm{g} / \mathrm{mL}, 500 \mu \mathrm{g} / \mathrm{mL}$ and $100 \mu \mathrm{g} / \mathrm{mL}$ of each tested essential oil, and $1 \%(10 \mathrm{mg} / \mathrm{mL})$ of DMSO. The mycelial discs (diameter $5 \mathrm{~mm}$ ) of 10-day-old F. graminearum CCM F-683 or F. graminearum CCM 8244 grown on PDA were transferred to the middle of the PDA surface in Petri dishes. The control for fungal growth was performed using Petri dishes containing only PDA with $10 \mathrm{mg} / \mathrm{mL}$ DMSO and the inoculum. Each EO concentration was tested in triplicate. The Petri dishes were incubated for 10 days in darkness at $25 \pm 2^{\circ} \mathrm{C}$. After incubation, the diameter of radial mycelium growth in the control and experimental groups 
was measured using a ruler. The mycelial growth inhibition

(\%) was calculated according the formula [22]:

$$
\text { The mycelial growth inhibition }(\%)=\frac{\mathrm{DC}-\mathrm{DT}}{\mathrm{DC}} \times 100
$$

DC - average diameters of fungal mycelia of control

DT - average diameters of fungal mycelia with essential oil

Statistical analysis. The data obtained were reported as means standard deviation (SD) and analysed using ANOVA assay; Dunnett test.

\section{RESULTS}

Table 1 shows the MICs of tested EOs and their inhibitory effect. In both strains, Fusarium graminearum CCM F-683 and Fusarium graminearum CCM 8244, the inhibitory effect of essential oils from Syzygium aromaticum, Origanum vulgare, Thymus vulgaris (Fig. 1) and Hyssopus officinalis was detected at the MIC value $0.4 \mathrm{mg} / \mathrm{mL}$. The inhibitory effect of Ocimum basilicum was observed at MIC $12.5 \mathrm{mg} / \mathrm{mL}$ in both strains of Fusarium graminearum. The MIC of Myristica fragrans essential oil was found to be $25 \mathrm{mg} / \mathrm{mL}$ for Fusarium graminearum CCM F-683, and at $50 \mathrm{mg} / \mathrm{mL}$ for Fusarium graminearum CCM 8244. The inhibitory effect of the EOs (\%) is illustrated in Figure 2.

Table 1. MIC values $(\mathrm{mg} / \mathrm{mL})$ and inhibitory effect $(\%)$ of EOs against Fusarium graminearum CCM F-683 and Fusarium graminearum CCM 8244

\begin{tabular}{lcccc}
\hline \multirow{2}{*}{$\begin{array}{l}\text { EO } \\
\text { EO }\end{array}$} & \multicolumn{2}{c}{ F. graminearum } & $\mathrm{CCM}$ F-683 & \multicolumn{2}{c}{ F. graminearum } & $\mathrm{CCM} 8244$ \\
\cline { 2 - 5 } Basil & $\mathrm{x} \pm \mathrm{SD}(\mathrm{mg} / \mathrm{mL})$ & $\mathrm{IE}(\%)$ & $\mathrm{x} \pm \mathrm{SD}(\mathrm{mg} / \mathrm{mL})$ & $\mathrm{IE}(\%)$ \\
\hline Myristica & $25.5 \pm 0$ & 40.1 & $12.5 \pm 0$ & 30.8 \\
\hline Syzygium & $0.4 \pm 0$ & 17.3 & $50.0 \pm 0$ & 6.2 \\
\hline Thymus & $0.4 \pm 0$ & 52.9 & $0.4 \pm 0$ & 24.8 \\
\hline Oregano & $0.4 \pm 0$ & 47.8 & $0.4 \pm 0$ & 41.0 \\
\hline Hyssop & $0.4 \pm 0$ & 31.3 & $0.4 \pm 0$ & 56.2 \\
\hline
\end{tabular}

$\mathrm{x}$ - average values of MIC; SD - standard deviation; IE - inhibitory effect

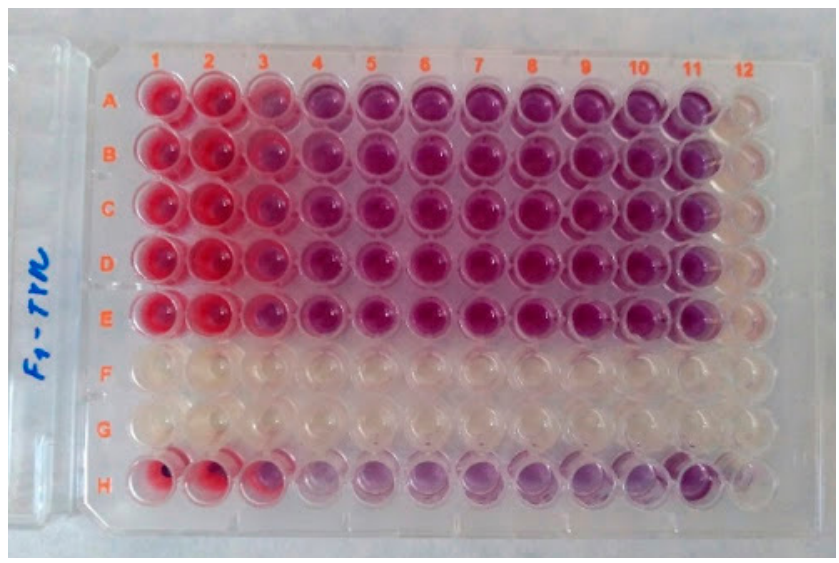

Figure 1. Inhibitory effect of Thymi aetheroleum on Fusarium graminearum CCM F-683, after adding $0.1 \%$ resazurin. Wells A-E: 5 test repetitions of Thymus vulgaris EO, 1-10: tested concentrations of EO

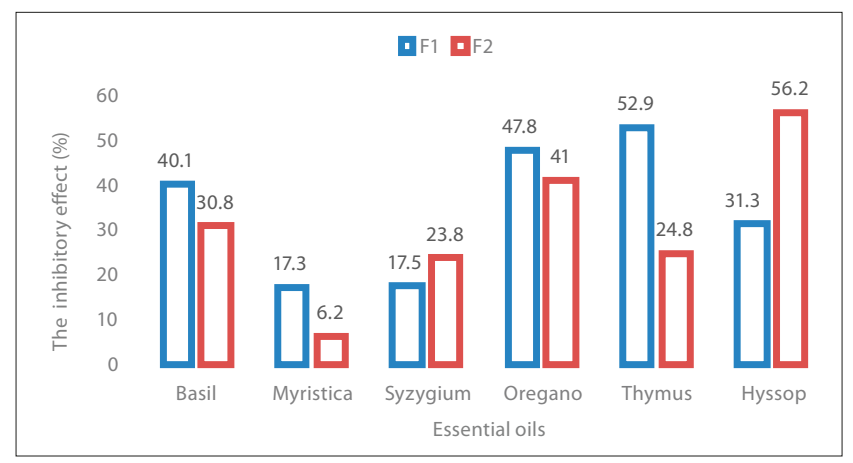

F1 - Fusarium graminearum CCM F-683, F2 - Fusarium graminearum CCM 8244

Figure 2. Inhibitory effect of essential oils (\%)

The EOs growth inhibition of mycelium at strain Fusarium graminearum CCM F-683 is shown in Table 2 and Figure 3. In the control Petri dishes, the average diameters of the fungal mycelium were $49.0 \pm 0 \mathrm{~mm}$. EOs of thymus, syzygium and oregano showed $100 \%$ efficacy at concentration $1,000 \mu \mathrm{g} / \mathrm{mL}$ and $500 \mu \mathrm{g} / \mathrm{mL}$, whereas their lower effect was recorded at the concentration $100 \mu \mathrm{g} / \mathrm{mL}$. The EO of hyssop was the least effective at each of the concentrations tested.

Table 2. Inhibition of mycelial growth (\%) of Fusarium graminearum CCM F-683 by EOs

\begin{tabular}{|c|c|c|c|c|c|c|}
\hline \multirow[b]{2}{*}{ EO } & \multicolumn{2}{|c|}{$1,000 \mu \mathrm{g} / \mathrm{mL}$} & \multicolumn{2}{|c|}{$500 \mu \mathrm{g} / \mathrm{mL}$} & \multicolumn{2}{|c|}{$100 \mu \mathrm{g} / \mathrm{mL}$} \\
\hline & $\begin{array}{l}x \pm S D \\
(\mathrm{~mm})\end{array}$ & $\begin{array}{c}1 \\
(\%)\end{array}$ & $\begin{array}{l}\mathrm{x} \pm \mathrm{SD} \\
(\mathrm{mm})\end{array}$ & $\begin{array}{c}1 \\
(\%)\end{array}$ & $\begin{array}{l}x \pm S D \\
(\mathrm{~mm})\end{array}$ & $\begin{array}{c}\text { I } \\
(\%)\end{array}$ \\
\hline Syzygium & $0^{* * *}$ & 100.0 & $0^{* * *}$ & 100.0 & $41.67 \pm 2.89^{* * *}$ & 15.0 \\
\hline Thymus & $0^{* * *}$ & 100.0 & $0^{* * * *}$ & 100.0 & $39.00 \pm 1.00^{* * *}$ & 20.4 \\
\hline Oregano & $0^{* * *}$ & 100.0 & $0^{* * *}$ & 100.0 & $30.67 \pm 1.53^{* * *}$ & 37.4 \\
\hline Hyssop & $37.67 \pm 1.15^{* * *}$ & 23.1 & $42.00 \pm 2.65^{* *}$ & 14.3 & $49.00 \pm 2.00$ & 0 \\
\hline
\end{tabular}



Figure 3. Inhibition of Fusarium graminearum CCM-683 mycelial growth

Similar results for the inhibitory effect of the tested EOs were recorded at Fusarium graminearum CCM 8244 (Tab. 3, Fig. 4). At concentration $1,000 \mu \mathrm{g} / \mathrm{mL}$ and $500 \mu \mathrm{g} / \mathrm{mL}$, the most effective (100\%) were the EOs of syzygium, thymus and oregano. The lowest inhibitory effect, at all examined concentration, was noted for the hyssop EO. Average diameter of fungal mycelium in the control samples $-50.0 \pm 0 \mathrm{~mm}$. 
Table 3. Inhibition of mycelial growth (\%) of Fusarium graminearum CCM 8244 by EOs

\begin{tabular}{lcccccc}
\hline & \multicolumn{2}{c}{$1,000 \mu \mathrm{g} / \mathrm{mL}$} & \multicolumn{2}{c}{$500 \mu \mathrm{g} / \mathrm{mL}$} & \multicolumn{2}{c}{$100 \mu \mathrm{g} / \mathrm{mL}$} \\
\hline EO & $\begin{array}{l}\mathrm{x} \pm \mathrm{SD} \\
(\mathrm{mm})\end{array}$ & $\begin{array}{c}\mathrm{I} \\
(\%)\end{array}$ & $\begin{array}{c}\mathrm{x} \pm \mathrm{SD} \\
(\mathrm{mm})\end{array}$ & $\begin{array}{c}\text { I } \\
(\%)\end{array}$ & $\begin{array}{c}\mathrm{x} \pm \mathrm{SD} \\
(\mathrm{mm})\end{array}$ & $\begin{array}{c}\text { I } \\
(\%)\end{array}$ \\
\hline Syzygium & $0^{* * *}$ & 100.0 & $0^{* * *}$ & 100.0 & $41.33 \pm 3.21^{* * *}$ & 17.3 \\
\hline Thymus & $0^{* * *}$ & 100.0 & $0^{* * *}$ & 100.0 & $39.33 \pm 1.15^{* * *}$ & 21.3 \\
\hline Oregano & $0^{* * *}$ & 100.0 & $0^{* * * *}$ & 100.0 & $29.67 \pm 1.15^{* * *}$ & 40.7 \\
\hline Hyssop & $39.33 \pm 0.58^{* * *}$ & 21.3 & $40.67 \pm 1.15^{* *}$ & 18.7 & $50.00 \pm 0.00$ & 0 \\
\hline
\end{tabular}

$x$ - mycelial growth diameters; SD - standard deviation; I (\%) - inhibition of mycelial growth ${ }^{*}-p<0.05 ;^{* *}-p<0.01 ;^{* * *}-p<0.001$ significantly different to control sample (ANOVA, Dunnett test)

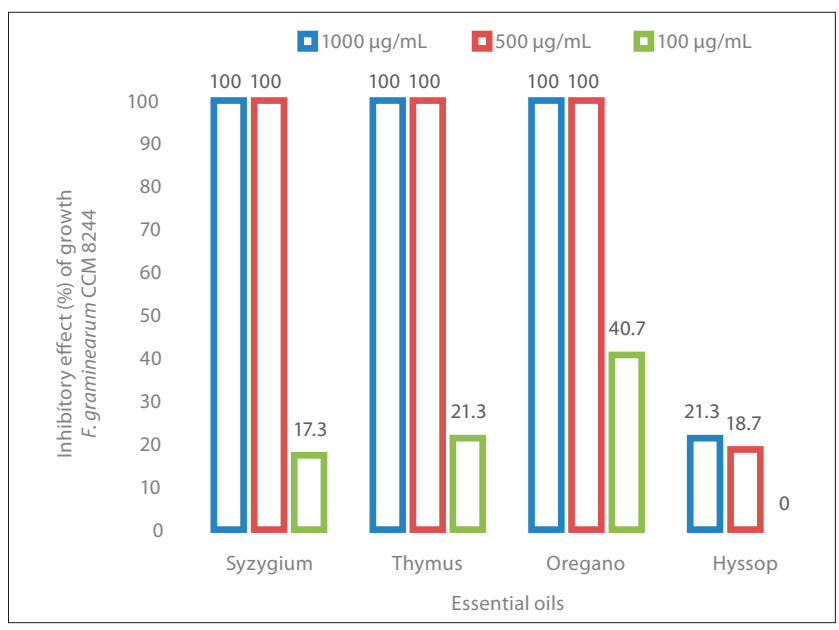

Figure 4. Inhibition of mycelial growth Fusarium graminearum CCM 8244

\section{DISCUSSION}

The elimination of the fungal contamination of crops is based on the use of chemical and physical methods. The greatest interest for the professional public is the use of natural substances, such as essential oils. The presented experiments confirmed the inhibitory effect of EO of thymus, oregano, syzygium and hyssopus at MIC $0.4 \mathrm{mg} / \mathrm{mL}$. EOs of oregano, thymus and syzygium showed the $100 \%$ inhibition activity of mycelial growth of both tested reference strains Fusarium graminearum CCM 8244 and Fusarium graminearum CCM 683 at concentrations $1,000 \mu \mathrm{g} / \mathrm{mL}$ and $500 \mu \mathrm{g} / \mathrm{mL}$. Similar results were also recorded in the study by Massoud et al. [23] in which thyme oil showed a highly performance in inhibiting Fusarium moniliforme, achieving 100\% growth inhibition with $5 \mu \mathrm{l} /$ plate and syzygium oil with $10 \mu \mathrm{l} /$ plate. KrzyśkoŁupicka et al. [24] tested the inhibition activity of lemon, rosewood, geranium and rosemary EOs, and compared their inhibitory effect on the linear growth of mycelium of the two strains, Fusarium graminearum ZALF 24 and Fusarium gramimearum ZALF 339. The tested concentrations of EOs were $1.25 \mathrm{mg} / \mathrm{mL}, 2.5 \mathrm{mg} / \mathrm{mL}, 5.0 \mathrm{mg} / \mathrm{mL}, 10.0 \mathrm{mg} / \mathrm{mL}$ and $20.0 \mathrm{mg} / \mathrm{mL}$. They observed $100 \%$ inhibition activity of geranium and rosewood oils in the mycelial growth of Fusarium graminearum ZALF 339 and ZALF 24 at each of the tested concentration. Rosemary oil showed the highest activity at a concentration of $5.0 \mathrm{mg} / \mathrm{mL}$ and lemon oil at $10.0 \mathrm{mg} / \mathrm{mL}$ against $F$. graminearum ZALF 339. The highest activity against $F$. graminearum ZALF 24 was recorded by the oils of rosemary and lemon at concentrations $10.0 \mathrm{mg} / \mathrm{mL}$ and $20.0 \mathrm{mg} / \mathrm{mL}$, respectively. $100 \%$ inhibition activity of thymus oil (Thymus vulgaris) on Fusarium culmorum was presented in a study by Matušinský et al. [16].

The results obtained in the current study revealed that oregano oil has the highest ability to inhibit the growth of Fusarium graminearum, which can be ascribed to the content of the phenolic compound (carvacrol) in this oil [25]. A similar affirmation of the antioxidant effect of carvacrol was presented in the study of Bouhdid et al. [26], which tested the antibacterial activity of the essential oil from Origanum compactum. The two phenols, carvacrol and thymol, are the main components of oregano oil with antioxidant effects [27]. Lucini et al. [28] indicated that the presence of monoterpenes in essential oils can cause mycelial growth inhibition. The monoterpenes could increase the concentration of lipid peroxides (hydroxyl, alkoxyl and alkoperoxyl radicals) and cause cell death [22]. Their effect is on the cell wall, the cell cycle, and also affect morphogenesis. The main constituents, a mixture of terpenoids, affect membrane permeability or cell wall biosynthesis. These abnormalities in the membrane structure result in leakage of cytoplasmic content and loss of cell viability of the pathogen [29]. They are capable of destroying a cell by a pro-oxidative effect on the membranes of pathogen cells or certain organelles [30].

In the current study, effective concentrations of essential oils against Fusarium graminearum were relatively low. It is necessary to investigate the antifungal effect of essential oils in the range of lower concentrations than used in this study, which could also be more cost effective. One of the direct uses of essential oils in agricultural practices is grain mordants, but further studies are needed.

\section{CONCLUSIONS}

Knowledge of antifungal effects of essential oils is of great importance in the field of biological plant protection. The use of essential oils may be an alternative to synthetic chemicals in the protection of plants against pathogenic fungi. All tested oils in this study showed some antifungal activity, but further studies are needed to evaluate the possible negative effects of essential oils on grain germination.

\section{REFERENCES}

1. Schiro G, Verch G, Grimm V, et al. Alternaria and Fusarium fungi: differences in distribution and spore deposition in a topographically heterogeneous wheat field. J Fungi. 2018; 4(2): 63. http://dx.doi. org/10.3390/jof 4020063

2. Rasiukevičiūtė N, Supronienė S, Kelpšienè J, et al. Susceptibility of non-cereal crops to Fusarium graminearum complex and their role within cereal crop rotation as a source of inoculum for Fusarium head blight. Span J Agric Res. 2018; 16(4): 1-12. https://doi.org/10.5424/ sjar/2018164-13952

3. McMullen M, Bergstrom G, De Wolf E, et al. A unified effort to fight an enemy of wheat and barley: Fusarium head blight. Plant Dis. 2012;96(12): 1712-1728. https://doi.org/10.1094/PDIS-03-12-0291-FE

4. FAO. Mycotoxins. Food Safety and Quality. 2013. http://www.fao.org/ food/food-s..

5. Ma LJ, Geiser DM, Proctor RH, Rooney AP, et al. Fusarium pathogenomics. Annu Rev Microbiol. 2013: 67: 399-416. https://doi. org/10.1146/annurev-micro-092412-155650

6. Häggblom P, Nordkvist E. Deoxynivalenol, zearalenone, and Fusarium graminearum contamination of cereal straw; field distribution; and sampling of big bales. Mycotoxin Res. 2015; 31(2): 101-7. https://doi. org/10.1007/s12550-015-0220-Z 
7. Moretti A, Pascale M, Logrieco AF. Mycotoxin risks under a climate change scenario in Europe. Trends Food Sci Tech. 2019; 84: 38-40. https://doi.org/10.1016/j.tifs.2018.03.008

8. Liew WPP, Mohd-Redzwan S. Mycotoxin: Its Impact on Gut Health and Microbiota. Front Cell Infect Microbiol. 2018: 8: 60. https://doi. org/10.3389/fcimb.2018.00060

9. Nesic K, Ivanovic S, Nesic V. Fusarial toxins: secondary metabolites of Fusarium fungi. Rev Environ Contam Toxicol. 2014; 228: 101-20. https://doi.org/10.1007/978-3-319-01619-1

10. Hennig-Pauka I, Koch FJ, Schaumberger S, et al. Current challenges in the diagnosis of zearalenone toxicosis as illustrated by a field case of hyperestrogenism in suckling piglets. Porcine Health Manag. 2018; 4(1): 18. https://doi.org/10.1186/s40813-018-0095-4

11. Patial V, Asrani RK, Thakur M. Food-borne mycotoxicoses: Pathologies and public health impact. In: Foodborne Diseases (Academic Press); 2018.p. 239-274. http://dx.doi.org/10.1016/B978-0-12-811444-5.00009-9

12. Antonissen G, Martel A, Pasmans F, et al. The impact of Fusarium mycotoxins on human and animal host susceptibility to infectious diseases. Toxins. 2014; 6(2): 430-452. https://doi.org/10.3390/ toxins6020430

13. Gundidza M, Gweru N, Magwa ML, et al. The chemical composition and biological activities of essential oil from the fresh leaves of Schinus terebinthifolius from Zimbabwe. Afr J Biotechnol. 2009; 8(24): 71647169. https://www.researchgate.net/publication/255614055_The chemical_composition_and_biological_activities_of_essential_oil_ from_the_fresh_leaves_of_Schinus_terebinthifolius_from_Zimbabwe (access: 2020.05.01).

14. Mahboubi M, Bidgoli FG. In vitro synergistic efficacy of combination of amphotericin B with Myrtus communis essential oil against clinical isolates of Candida albicans. Phytomedicine. 2010; 17(10): 771-4 https://doi.org/10.1016/j.phymed.2010.01.016

15. Mazari K, Bendimerad N, Bekhechi C. Chemical composition and antimicrobial activity of essential oils isolated from Algerian Juniperus phoenicea L. and Cupressus sempervirens L. J Med Plants Res. 2010; 4(10): 959-964. https://doi.org/10.5897/JMPR10.169

16. Matušinský P, Zouhar M, Pavela R, et al. Výzkum alternatívnych zpusobu ochrany obilnín proti houbovým patogénum. Obilnářske listy. 2016; 24(2): 38-40. https://www.vukrom.cz/userfiles/files/obilnarske_ listy/2016/2016_2/38-40.pdf (access: 2020.05.12).

17. Cowan MM. Plant products as antimicrobial agents. Clin Microbiol Rev. 1999; 12(4): 564-82. https://doi.org/10.1128/CMR.12.4.564

18. Solórzano-Santos F, Miranda-Novales MG. Essential oils from aromatic herbs as antimicrobial agents. Curr Opin Biotechnol. 2012; 23(2): 136-41. https://doi.org/10.1016/j.copbio.2011.08.005

19. Perczak A, Gwiazdowska D, Gwiazdowski R, et al. The Inhibitory Potential of Selected Essential Oils on Fusarium spp. Growth and
Mycotoxins Biosynthesis in Maize Seeds. Pathogens. 2020;9(1):23. https://doi.org/10.3390/pathogens9010023

20. Hadacek F, Greger H. Testing of antifungal natural products: methodologies, comparability of results and assay choice. Phytochem Anal. 2000; 11(3): 137-47. https://doi.org/10.1002/(SICI)10991565(200005/06)11:3<137::AID-PCA514>3.0.CO;2-I

21. Kumar P, Mishra S, Kumar A, et al. Antifungal efficacy of plant essential oils against stored grain fungi of Fusarium spp. J Food Sci Tech. 2016;53(10):3725-34. https://doi.org/10.1007/s13197-016-2347-0

22. Badawy ME, Abdelgaleil SA. Composition and antimicrobial activity of essential oils isolated from Egyptian plants against plant pathogenic bacteria and fungi. Ind Crops Prod. 2014; 52: 776-82. https://doi. org/10.1016/j.indcrop.2013.12.003

23. Massoud MA, Saad AS, Soliman EA, et al. Antifungal activity of some essential oils applied as fumigants against two stored grains fungi. J Adv Agric Res (Fac Agric Saba Basha). 2012; 17(2): 296-306. https:// www.researchgate.net/publication/293817314_Antifungal_activity_ of_some_essential_oils_applied_as_fumigants_against_two_stored_ grains_fungi (access: 2020.05.11).

24. Krzyśko-Łupicka T, Walkowiak W, Białoń M. Comparison of the fungistatic activity of selected essential oils relative to Fusarium graminearum isolates. Molecules. 2019; 24(2): 311. https://doi. org/10.3390/molecules24020311

25. Chun SS, Vattem DA, Lin YT, et al. Phenolic antioxidants from clonal oregano (Origanum vulgare) with antimicrobial activity against Helicobacter pylori. Process Biochem. 2005; 40(2): 809-16. https:// doi.org/10.1016/j.procbio.2004.02.018

26. Bouhdid S, Skali SN, Idaomar M, et al. Antibacterial and antioxidant activities of Origanum compactum essential oil. Afr J Biotechnol. 2008; 7(10): 1563-1570. https://www.researchgate.net/ publication/215442494_Antibacterial_and_antioxidant_activities_ of_Origanum_compactum_essential_oil (access: 2020.05.30).

27. Mechergui K, Coelho JA, Serra MC, et al. Essential oils of Origanum vulgare L. subsp. glandulosum (Desf.) Ietswaart from Tunisia: chemical composition and antioxidant activity. J Sci Food Agric. 2010; 90(10): 1745-1749. https://doi.org/10.1002/jsfa.4011

28. Lucini EI, Zunino MP, López ML, et al. Effect of monoterpenes on lipid composition and sclerotial development of Sclerotium cepivorum Berk. J Phytopathol. 2006; 154(7-8): 441-6. https://doi.org/10.1111/j.14390434.2006.01126.x

29. Raut JS, Karuppayil SM. A status review on the medicinal properties of essential oils. Ind Crops Prod. 2014; 62: 250-64. https://doi. org/10.1016/j.indcrop.2014.05.055

30. Stringaro A, Vavala E, Colone M, et al. Effects of Mentha suaveolens essential oil alone or in combination with other drugs in Candida albicans. Evid Based Complement Alternat Med. 2014;2014. https:// doi.org/10.1155/2014/125904 